\title{
Cabin in the Pines: Albert Music Hall and Constructions of a Pine Barrens Musical Tradition By Christine A. Lutz
}

DOI: http://dx.doi.org/10.14713/njs.v2i2.47

Albert Music Hall is an outpost of bluegrass, folk, and country music in the New Jersey Pine Barrens, offering hours of live music every Saturday night. It has formally been in existence since the 1970s under the auspices of the Pinelands Cultural Society, but it traces its roots back to the 1950s, when brothers Joe and George Albert started hosting informal musical gatherings at their Pines fox hunting cabin, known in the area as the "Homeplace." What started as locals playing old-time and country music at a rustic cabin deep in the woods has evolved into a more formal venue that features musicians from around New Jersey and beyond. Albert Music Hall has persisted as an island of an older, more rural, and isolated Pines in an industrialized, urbanized state. Through an examination of the language, material culture, and music of the venue, this paper considers questions and constructions of authenticity in relation to notions of what a true Pine Barrens musical experience might be for Albert Music Hall audiences and musicians.

Albert Music Hall is a live country, bluegrass, and folk music venue located on the edge of the Pine Barrens in Waretown, New Jersey. For over 40 years, the Pinelands Cultural Society has promoted the hall as a site that preserves, fosters, and honors what they call the "Sounds of the Jersey Pines" and the memory of brothers and musicians Joe and George Albert. ${ }^{1}$ Albert Music Hall traces its roots to casual musical gatherings at the brothers' cabin, during an older

\footnotetext{
${ }^{1}$ I would like to thank Dr. Nicole King for reading an early draft of this article. Thanks to Roy Everett, Pinelands Cultural Society President, and Elaine Everett, Pinelands Cultural Society Public Relations Committee Chairperson, for their assistance with details about Albert Music Hall and its history and for patiently answering my questions. Thanks to Dr. Angus Kress Gillespie for sharing archival material and discussing early Pinelands Cultural Society and Albert Hall history. Thanks also to Dr. David J. Fowler for conversations about Pine Barrens history and culture.
} 
time, in a more rural and isolated Pine Barrens. Yet this seemingly anomalous music venue persists, indeed thrives, in the midst of ever-encroaching suburban sprawl and unbridled development and industry. On any given Saturday night, local retirement community crowds, handfuls of hipsters, and Pine Barrens natives pack Albert Music Hall to listen to musicians on banjo, fiddle, and mandolin in an alcohol-free, family-friendly environment.

It is hard to believe that Albert Music Hall sits between two iconic and very different New Jersey musical scenes. Just over an hour south of Waretown, the postwar boom helped create Wildwood, a vacation destination of sun, sand, and artificial palm trees. During the 1950s and 60s, the time when the Albert brothers and their friends were playing old folk tunes and ballads in their cabin in the Pines, Wildwood developed as a site where the most famous rock and roll and doo-wop performers of the day played music with African American, urban roots. About forty minutes north of Waretown, the R\&B and soul-influenced Jersey Shore Sound was starting to flourish along the north Jersey shore, most notably in Asbury Park, at the same time Albert Music Hall's first iteration, referred to as "Sounds of the Jersey Pines," was being established in Waretown in the early 1970s. Albert Music Hall's Pine Barrens locale is a far cry from the gritty, seaside carnival atmosphere of Bruce Springsteen's Asbury Park, as well as from that city's more recent reincarnation as a haven for artists, foodies, and developers.

In creating the Sounds of the Jersey Pines and Albert Music Hall, the Pinelands Cultural Society constructed a certain authenticity. That is, the members of the organization both explicitly and implicitly worked to create and maintain a sense of legitimacy and believability that the Albert Music Hall audience would accept as a true and authentic Pine Barrens musical experience. That experience included an awareness that there was a purer, more pristine and rustic Pine Barrens in which this music thrived. Several aspects of the Society's work 
demonstrate their particular construction of authenticity well. First, their precise choice of language during the critical time when they moved from the Alberts' cabin, known as the Homeplace, to their next home in the Waretown Auction Hall; second, the material culture of the current Albert Music Hall; and third, the music that members of the original Pinelands Cultural Society and others have performed from the time of the Homeplace through to the current hall. Through all of these efforts the Pinelands Cultural Society reconstructed their beloved cabin in the pines.

There are a couple of points regarding authenticity that are particularly useful for looking at the language, material culture, and music of Albert Music Hall. In considering the authenticity of folk singers leading up to the mid- $20^{\text {th }}$ century folk revival, Benjamin Filene traced its criteria, or construction, to Alan and John Lomax's work to create what he calls a "cult of authenticity" that folk musicians are influenced by and negotiate to this day. ${ }^{2}$ As Filene states:

just as isolated cultures became harder to define and locate in industrialized America, the notions of musical purity and primitivism took on an enhanced value....twentieth century American have been consistently searching for the latest incarnation of 'old-time' and 'authentic' music. Such terms may have lost their referents, but their cultural power has remained undiminished. ${ }^{3}$

Second, there is the following definition of folk music:

The community has a role in adopting or rejecting songs. It is also recognized that not all songs are ancient, and that folk repertories are constantly changing. Change may be spontaneous (innovation) or stimulated by contact with another group of people (acculturation); new songs are composed, and old ones discarded or put to new uses; modes, scales, and rhythms may be changed. ${ }^{4}$

\footnotetext{
2 Benjamin Filene, Romancing the Folk: Public Memory and American Routes Music (Chapel Hill: The University of North Carolina Press, 2000), 49.

${ }^{3}$ Ibid., 3.

${ }^{4}$ Helen Myers and Peter Wilton, "Folk music," The Oxford Companion to Music. Oxford Music Online. Oxford University Press, accessed December 4, 2015, http://www.oxfordmusiconline.com.proxy.libraries.rutgers.edu/subscriber/article/opr/t114/e2609.
} 
As we will see, the Pinelands Cultural Society initially developed a "cult of authenticity" around Joe and George Albert and musicians among their number who were natives of the Pine Barrens. As time went on, songs moved in and out of Albert Music Hall musicians' repertoires, especially as musicians and audience members traveled from further afield to attend Saturday night concerts. Yet the lure and power of the authentic Pine Barrens narrative remains a force today even amid the shifting paradigm of what constitutes an authentic Pine Barrens musical experience.

In his 1968 book The Pine Barrens, John McPhee chronicled the natural environment, people, and folklore of this sandy-soiled, vast expanse of pine and oak trees that covers about one fifth of southern New Jersey..$^{5}$ Although others had written about the natural features and folklore of the Pines before then, namely Henry Charlton Beck, McPhee put the Pine Barrens on the cultural map and into the consciousness of Americans.

Joe and George Albert make appearances, albeit brief, in some Pine Barrens literature dating to the 1970s. ${ }^{6}$ David Steven Cohen, among others, notes that the Albert brothers were fox hunters and musicians, and provides a short description of today's Albert Music Hall in his book Folk Legacies Revisited (New Brunswick, NJ: Rutgers University Press, 1995). The Albert brothers have a more substantial role in Mary T. Hufford's dissertation turned book Chaseworld: Foxhunting and Storytelling in New Jersey's Pine Barrens (Philadelphia: University of

\footnotetext{
${ }^{5}$ Emily W. B. Russell, "Pine Barrens," in The Encyclopedia of New Jersey, eds. Maxine Lurie and Marc Mappen (New Brunswick, NJ: Rutgers University Press, 2004), 637.

${ }^{6}$ While this article focuses on Albert Music Hall and the Pinelands Cultural Society it should be noted that folklorist Herbert Halpert collected songs on a trip to the Pine Barrens in 1939. These recordings have been deposited at the Archives of Traditional Music at Indiana University, Bloomington. Song titles and some texts are extant. He collected a variety of songs including work songs, ballads and sea shanties. He authored two articles on music of the Pines published the same year: "Piney Folk Singers: Interviews, Photos, and Songs," Direction 2 (1939): 4-6 and "Some Ballads and Folk Songs from New Jersey," Journal of American Folklore 52 (1939): 52-69. Halpert included the material he collected in his dissertation, Folktales and Legends of the New Jersey Pines: A Collection and Study. A comparative look at the songs Halpert collected and those the Pineconers and later musicians played, while outside the scope of this article, could shed more light on the repertoire of later Pine Barrens musicians.
} 
Pennsylvania Press, 1992). While she discusses the Alberts and the Homeplace in terms of the fox hunting culture of the Pines, she does not address their musical side. Hufford had previously briefly mentioned Joe Albert and Janice Sherwood, a founding member of the Pinelands Cultural Society and member of the important Pine Barrens band, the Pineconers, in One Space, Many Places: Folklife and Land Use in New Jersey's Pinelands National Reserve (Washington, D.C.: American Folklife Center, Library of Congress, 1986). William McMahon, in his book Pine Barrens Legends and Lore (Moorestown, NJ: Middle Atlantic Press, 1980) devotes a chapter to Pine Barrens music and discusses the history of the Pinehawkers, a trio of Pines natives who started playing together prior to World War II and broke up shortly thereafter. McMahon moves into a discussion of the Pineconers along with Joe and George Albert and he notes some of the band's regular Albert Hall repertoire at that time. Examples include audience favorites such as "Wabash Cannonball," "Bill Bailey" and "Green, Green Grass of Home." There were also originals in their repertoire that pertained to the locality including "Come on Down to Waretown," "Home in the Pines," and "Homeplace."7

In the foreword to the edited volume Pinelands Folklife (New Brunswick, NJ: Rutgers University Press, 1987) former director of the American Folklife Center at the Library of Congress Alan Jabbour recounts a 1977 trip to a Saturday Night Jamboree at what was then known as Albert Hall or Sounds of the Jersey Pines, and relays a brief history of how the venue came to be. He also presents a snapshot of the repertoire of the musicians of the time consisting of songs that document Pine Barrens life. More recently, photographer Bob Birdsall included photographs of people who are part of the Albert Music Hall community in his book entitled People of the Pines (Medford, NJ: Plexis Publishers, 2007).

\footnotetext{
${ }^{7}$ William McMahon, Pine Barrens Legends and Lore, (Moorestown, NJ: Middle Atlantic Press, 1980$), 117$.
} 
Folklorist Angus Gillespie, along with fellow folklorist Tom Ayres, spent perhaps the most time considering Pine Barrens music, and visited Albert Hall regularly in the 1970s, talking with the musicians and volunteers. ${ }^{8}$ Both wrote about Pinelands music in papers drawn from their presentations at the First Research Conference on the New Jersey Pine Barrens, held in May 1978. In "The Pinelands Cultural Society: Folk Music Performance and the Rhetoric of Regional Pride," Ayres undertook "an analysis of how the Pinelands Cultural Society utilizes folk music performance as a rhetorical device" to combat "encroaching 'suburbanization' and the attendant clash between rural and urban value systems that it brings with it." 9 Gillespie, meanwhile, examined the repertoire of the Pineconers, in particular the role of Gladys Eayre, the guitar player and one of the group's vocalists, as caretaker of their repertoire. ${ }^{10}$

Since the 1990s, Albert Music Hall has been featured in popular New Jersey and regional newspapers and magazines. Journalists have focused on Albert Music Hall as a stop among other Pine Barrens tourist destinations, as a venue for country and bluegrass fans, and as a site of Pine Barrens cultural uniqueness and tradition. ${ }^{11}$

The story of Albert Music Hall begins in 1932 when Joe Albert, a full-time mason and roofer and part-time fox hunter and musician from suburban Sayreville, in central New Jersey,

\footnotetext{
${ }^{8}$ Angus Gillespie, in conversation with the author, July 2015. Gillespie also introduced Jabbour to Albert Hall, which Jabbour also notes in his Pinelands Folklore foreword.

${ }^{9}$ Tom Ayres, "The Pinelands Cultural Society: Folk Music Performance and the Rhetoric of Regional Pride" in Natural and Cultural Resources of the New Jersey Pine Barrens: Inputs and Research Needs for Planning, 1978, edited by John W. Sinton (Pomona, NJ: Center for Environmental Research, Stockton State College, 1979), 225, 228.

${ }^{10}$ Angus Gillespie, "Folk and Hillbilly Music in the Pines: Gladys Eayre and the Pineconers' Repertoire" in Natural and Cultural Resources of the New Jersey Pine Barrens: Inputs and Research Needs for Planning, 1978, edited by John W. Sinton (Pomona, NJ: Center for Environmental Research, Stockton State College, 1979). The authors distilled both papers into an article entitled "Folklore in the Pine Barrens: The Pinelands Cultural Society," New Jersey History XCVII, no. 4 (Winter 1979): 221-243.

${ }^{11}$ Two of the more recent articles on Albert Music Hall to be published in journalistic media outlets are Lisa Rose, "Old-Timey Music in Ocean County Has a Home at the Albert Music Hall," NJ.com, August 9, 2013, accessed December 5, 2015, http://www.nj.com/entertainment/index.ssf/2013/08/oldtimey_music_in_ocean_county_has_a_home_at_the_albert_music_hall.html and Fred Goodman, "Lost in the Pines," New Jersey Monthly, September 13, 2011, accessed December 5, 2015, http://njmonthly.com/articles/jersey-living/lost-in-the-pines.
} 
purchased 51 acres of land deep in the Pine Barrens. Unhappy with his work and the increasing urbanization of his hometown, Joe quit working in 1939 at the age of 41 and moved permanently to the fox hunting cabin he had built on his property with the assistance of his hunting friends. The Homeplace, as the cedar shingle cabin was known, featured a roof of repurposed tin and had no running water or electricity. Joe Albert now had the quiet, rural existence he craved deep in the woods near Waretown. On weekends, though, he welcomed his brother George down from Sayreville, along with a small, close-knit group of hunter and musician friends including a band known as the Pineconers that included Joe on washtub bass and George on fiddle. In time the gatherings became known as Saturday Night Jamborees. These were casual, homey gatherings. To sustain music making long into the night, someone always made coffee, and local women brought their homemade desserts. The Pineconers and others drew their repertoire from old songs brought to the Pines by English settlers, some of the songs having been passed down through their families. But they also played songs they wrote about life and work in the Pines. ${ }^{12}$

Over the course of nearly twenty years, the jamborees grew increasingly popular with Pines residents and outsiders alike. In 1957, the Garden State Parkway, which runs along the eastern edge of the Pines, increased access to the area. By 1974, the year that George Albert died, the jamborees had outgrown the cabin, and an unwelcome element, primarily young adults, moved into the woods. These newcomers introduced alcohol and drugs to the gatherings. As a result of the overcrowding and the undesirable behavior, Joe put an end to musical nights at the Homeplace.

A core group of musicians that included Joe Albert and the Pineconers intensely missed the music and the camaraderie of the jamborees. After roughly six months of this hole in their lives, the musicians started looking for a place to carry on the music and spirit of the Homeplace

\footnotetext{
${ }^{12}$ Angus Kress Gillespie, "folklore" in The Encyclopedia of New Jersey, 278-280.
} 
gatherings. A chance meeting led to the opportunity to revive the Saturday Night Jamborees at an auction hall on Route 9 in Waretown. The Pineconers and several others organized themselves into the Pinelands Cultural Society. They met at the Homeplace to craft plans and policies for the new "home." Their mission was threefold: "to build a music hall called "Albert Hall," in Waretown if possible; to encourage "new musicians" to "continue in the same pattern instituted by the Albert brothers;" and to "present to the public good entertainment at a minimal cost so as to make the music as accessible as possible." ${ }^{13}$ The public paid fifty cents to attend, and musicians signed up to play a set.

In 1992, the auction hall burned down. The Pineconers and others continued to play Saturday night sets in the hall's parking lot for a time, and eventually moved into a Waretown elementary school. By 1995 the Pinelands Cultural Society mounted a fundraising effort for a new, permanent home for the hall. In February of that year, a bill approved by the Senate \& General Assembly of the State of New Jersey allowed "conveyance of real estate to a non-profit historic preservation organization to provide a place for educational, cultural, and musical functions." 14

Albert Music Hall as it stands today opened in 1997, and offers live, acoustic country, bluegrass, and folk music every Saturday night from 7:30pm until 11:30pm, and often later. Under the auspices of the Pinelands Cultural Society, the venue was largely built by volunteers, including musicians who play there. The 6,000 square foot, 350-seat, two-story, rectangular structure is a modern, utilitarian building with gestures towards a likeness to the Alberts' cabin. The roof is covered in asphalt shingles and the exterior features beige vinyl siding. An eight-foot

\footnotetext{
${ }^{13}$ Press release for Dry Dock Inn benefit, August 31, 1975, Pinelands Cultural Society Records (MC930), Box 1, "Notes to Press" folder, Special Collections and University Archives, Rutgers University Libraries.

14 "Chronological Fact Sheet," Albert Music Hall, accessed November 1, 2015, http://www.alberthall.org/ChronologicalFactSheet.htm.
} 
wide open font porch constructed of cement with spindle style railings and posts painted a reddish brown runs the length of the Hall's front and provides a space for musicians to gather and jam. Evoking the style of the Alberts' cabin, the building has a double front gable, with an additional smaller front gable in the center of the porch's shed style roof. The Pinelands Cultural Society symbol of a banjo and mandolin with crossed necks and intertwined with a pine bough is affixed prominently to the front of the building.

The first floor of the building contains the public space, while the second floor provides storage and office space. Visitors proceed up a cement ramp from a large parking lot towards double glass doors. Some visitors might opt to remain on the porch for a while listening to musicians or greeting friends. Through the doors, concertgoers enter into a brightly lit, spacious foyer. There they line up to pay admission $-\$ 5$ for adults and $\$ 1$ for children and 50-50 tickets for later in the night, when the evening's host takes the stage between sets to call out the winning numbers and make announcements. Some visitors mill around the lobby, greeting friends, reading musicians' notices, or viewing the permanent exhibit on the Albert brothers and the history of the venue named for them. The sound booth sits straight ahead, with aisles on either side that lead into the main section of the Hall. A concession stand is located to the left of the sound booth, with offerings such as hot dogs, cake, and coffee, all made and served by volunteers. To the right is a small gift shop where volunteers sell an array of Pinelands and Jersey Devil merchandise, from bumper stickers to t-shirts to books and CDs.

The main interior walls of the hall are twelve feet high and made of standard wallboard, and exposed dark brown scissor trusses raise the interior space to approximately twenty-two feet at the center. ${ }^{15}$ The lower halves of the interior walls are covered in carpet and above the carpeted area photos and newspaper and magazine clippings share wall space with instruments

\footnotetext{
${ }^{15}$ Everett, Roy, e-mail message to author, April 21, 2016.
} 
and indigenous tools. The carpet and the items hanging on the walls help keep the sound from bouncing around the building. ${ }^{16}$ Four warm-up rooms behind the stage, the back wall of the stage, and restrooms are all soundproofed. The design of the main part of the interior was carried over from the Waretown Auction site and maintains an intimacy between musicians and audience. ${ }^{17}$ The stage set, which will be described in detail later in this paper, was designed to vaguely resemble the Albert brothers' cabin front porch.

Albert Music Hall fronts what appears to be an ample parking lot, but at the height of the summer season, it is not big enough to hold all of the cars that pour in over the course of a Saturday evening. Indeed, in the summer, if visitors do not arrive when doors open at 6:30 for the 7:30 show, they will find that the Hall is standing room only. The venue operates 50 weeks of the year, with special concerts for holidays and anniversaries, not to mention an annual "Jersey Devil Show" and "Home Place Festival," which honors the Albert brothers and the bygone jams at their cabin in the woods. Albert Music Hall is all-volunteer run, and proceeds go to the Pinelands Cultural Society in order for them to preserve the "singular style of musical gathering, including its unique ambience" in a "living history format." 18 Proceeds also go to the Albert Music Hall Scholarship Fund, which provides academic awards each year to four graduating seniors from Southern Regional High School in Ocean County.

Musicians who perform on the main stage are selected by a small group of Pinelands Cultural Society members. There are seven half-hour sets each night. Most musicians come from New Jersey, New York, and Pennsylvania, some stopping while passing through on vacation, others making a planned tour stop. Many of the regulars have their own followings. Although

\footnotetext{
16 Ibid.

17 Ibid.

18 “Frequently Asked Questions," Albert Music Hall, accessed November 1, 2015, http://www.alberthall.org/UnderstandingPCSandAMH.htm.
} 
musicians rehearse in the backstage practice rooms before their sets, their performances may be spontaneous, and reflect the mood or character of the audience that night. On any given evening, the audience may hear a wide-ranging selection of country, bluegrass, and folk. This may include original, new songs about the Jersey Pines, or old murder ballads, gospel tunes, or dance or social music. The musicians might also cover a range of artists, and those typically covered include the following: the Carter Family, Jimmie Rodgers, Ralph Stanley, Hank Williams, Bill Monroe, Patsy Cline, Elvis, Merle Haggard and John Prine. The audience, largely consisting of senior citizens, pays rapt attention to the musicians on stage, often singing or clapping along when a familiar song is played, and always giving the performers an enthusiastic round of applause. While musicians are on the main stage, informal song swapping and jamming is happening on the front porch and in the six hundred square foot, garage-style Pickin' Shed, and even out in the parking lot in tailgating fashion. Adjacent to Albert Music Hall, the Pickin' Shed, in particular, is a place to learn, practice, or just listen, at no cost. A bright green carpet and yellow walls give the space a bright, cheerful ambiance. Under paintings of country musicians and old Albert Music Hall signs, musicians sit in a circle and play at their own abilities. Many of the pickers there use it as a place to hone their musical skills. Indeed, many of the main stage musicians and bands had their start in the shed. Albert Music Hall lore includes the story of a boy whose mother regularly drove him to the Pickin' Shed on Saturday nights, where he apprenticed himself to some of the musicians. A teenager now, he has moved on to the main stage and has a loyal following. The Pickin' Shed jam continues on well past 11:30pm, when the last band leaves the main stage. Sometimes, the last band of the night will bring the Pickin' Shed players up on stage with them to close out the gathering. 
The current set-up in Waretown is very different from the first post-Homeplace iteration although its founders set the stage, so to speak, for what the board and musicians of Albert Music Hall strive to be today. On November 29, 1974 the Pinelands Cultural Society held their first show at the Waretown Auction Hall, calling it The Sounds of the Jersey Pines. Memos in the archival records of the society document the move from the cabin to the auction hall and in doing so reveal that the musician-organizers both explicitly and implicitly constructed, negotiated, and defined their new venture and venue in terms of traditional values of family and home, values that held sway at the Homeplace cabin. In an early report the Pinelands Cultural Society declares, "Wherever it meets that is its home, and it's on the family concept that its physical government should function. The hosts are the head of the house, the musicians and audience are the family." They cast George and Joe Albert as benevolent grandfathers. ${ }^{19}$

The influence of the original Homeplace as well as the term "homeplace" itself was strong as the Society went about negotiating the terms of their new undertaking. Michael Ann Williams defines "homeplace" in her book of the same title as a "home of the past," a "place that has meaning" that is generally applied to the place where one is raised. ${ }^{20}$ As such, strong symbolic meaning is ascribed to the homeplace. ${ }^{21}$ The musicians who spent every Saturday night at the cabin clearly saw it as a family home. The language of family they chose to use in the rules and policies they developed ahead of their first night at the Waretown Auction Hall reflect their feelings, memories, and emotions around the Alberts' cabin. That the Society designated Joe and George Albert as grandfathers of the Sounds of the Jersey Pines plays to Filene's notion of the "cult of authenticity." There would be a constant reminder, for the musician-organizers,

\footnotetext{
${ }^{19}$ Anniversary edition newsletter, undated, Pinelands Cultural Society Records. Box 1, "Miscellaneous" folder. ${ }^{20}$ Michael Ann Williams, Homeplace: The Social Uses and Meaning of the Folk Dwelling in Southwestern North Carolina (Athens: The University of Georgia Press, 1991), 117.

21 Ibid., 36-37.
} 
visiting musicians, and audience that the Alberts would be upheld as shining examples of Pine Barrens musical authenticity.

The Pinelands Cultural Society's notion of visiting musicians and the audience as family was complicated, though, by their desire to combat the threat they felt to their environment by development and urbanization. Angus Gillespie, who regularly attended shows at the Waretown Auction, asserts that the Pineconers and other performers used their music to fight this threat and has asserted that "outsider values are in conflict to their own." 22 This is seen in their rejection of outsiders at the Homeplace gatherings. The unspoken but very clear underlying current is that these outsiders were welcomed like family as long as they were respectful of the Pinelands Cultural Society's values, followed the rules, and engaged with the music and reverential atmosphere. Further, like parents enforcing house rules, the society emphasized that alcohol and drugs were frowned upon and not permitted at the venue. Indeed, host duties included "checking often for gate crashing and no drugs (alcohol, etc.). ${ }^{, 23}$ The rules that applied to the audience also applied to the musicians. Hosts also needed to "maintain discipline" and ensure children were not running around. ${ }^{24}$

The larger story reflected in the rules that the Pinelands Cultural Society wrote is one of negotiating change. When John McPhee wrote The Pine Barrens in the late 1960s he described a place whose people and their lifestyle and their work, along with the natural resources around them, were under threat from outside influences including development and technology. While the new iteration of the musical nights welcomed bands from out of the area and visitors from outside the Pines who wanted to hear the music, both the native and assimilated Pines residents

\footnotetext{
${ }^{22}$ Angus Gillespie, unpublished manuscript draft shared with the author.

23 "Duties of the Co-hosts" memo, undated, Pinelands Cultural Society Records, Box 1, "Schedule of Music, Concert Info" folder.

24 Ibid.
} 
surely felt threatened. Not surprisingly, around this same time the Pinelands Cultural Society created bumper stickers with the motto "Piney Power" in an effort to reclaim a negative stereotype. In her unpublished memoir, Pines native Janice Sherwood wrote that she was lucky that she "knew the Pines before the migration from the north and west began" and that "the Jersey I wish would stay, is leaving us." 25 Of course, the Alberts were not natives of the Pine Barrens, but they fit seamlessly into the culture. Not only did they play the old music, but they were also heavily invested in the Pine Barrens activity of fox hunting, and Joe, at least, had a strong disdain for urbanization.

So while it may seem nostalgic or sentimental, even backwards-looking to cling to the idea of a homeplace, the Pinelands Cultural Society members used the idea of the homeplace to further their cause and promote and preserve a piece of New Jersey that could disappear. They constructed what Richard A. Peterson, in his book Creating Country Music, Fabricating Authenticity refers to as a "rustic alternative to modern urbanity." 26 They coped with threats to their worlds--natural, musical and familial--by literally building a sacred musical home, a symbol of an authentic rural Pine Barrens hunting cabin, and in doing so also constructed a presence through their musicianship and repertoire that was convincingly authentic to the locals and those outside the Pines who came to Albert Music Hall.

As we will see, the repertoire of the Sounds of the Jersey Pines reflects a common theme in country music: separation from home, in particular a rural home, and family. ${ }^{27}$ As rural southerners moved to northern, industrial cities in the first half of the $20^{\text {th }}$ century, romanticized

\footnotetext{
${ }^{25}$ Janice Britton Sherwood, “Tunes and Tales,” (unpublished manuscript, 1999), Special Collections and University Archives, Rutgers University Libraries, 1.

${ }^{26}$ Richard A. Peterson, Creating Country Music, Fabricating Authenticity (Chicago: The University of Chicago Press, 1997), 55.

${ }^{27}$ Michael Ann Williams and Larry Morrisey, "Constructions of Tradition: Vernacular Architecture, Country Music, and Auto-Ethnography," Vernacular Architecture Forum, Perspectives in Vernacular Architecture, 8 (2000): 162, accessed December 1, 2015, doi: 10.2307/3514412.
} 
images began appearing more frequently in country music lyrics. These images were, often, of rural vernacular structures, such as the family cabin. ${ }^{28}$

Williams states that "the homeplace is often preserved through narrative rather than physical rehabilitation of the structure itself," 29 and indeed the archival record of the Pinelands Cultural Society demonstrates that they focused on the non-material aspects and the experience of the Homeplace above other matters. They focused on the feelings of attendees, the atmosphere of the Homeplace. They stated that their primary purpose was to preserve the spirit of the Albert cabin gatherings. Yet in an early press release the Pinelands Cultural Society waxes nostalgic about the "gas lit cabin with only a pitcher pump for water" and the "old fashion (sic) cook stove" that was "Heaven." ${ }^{30}$ Here, the Pinelands Cultural Society members betrayed a longing for the material aspects, the "stuff," of the cabin that itself evokes strong emotions and memories. In this same press release the Pinelands Cultural Society refers to the "Albert Hall" they are hoping to raise money to construct as "a music hall in the tradition of the Grand Ole Opry in Nashville, but alive and living in Ocean County." ${ }^{31}$ Here they self-designate a "little opry" ${ }^{\prime 2}$ not unlike the Carter Family Fold in Virginia. Such reverential sites contain the material trappings of the musicians who inhabited them, either as homes or in the case of the Grand Ole Opry, whose home, Ryman Auditorium, had been a church, a literal spiritual and musical home. Part of the Carter Family Fold complex, for example, is a museum that is in essence a shrine to A.P., Sara, and Maybelle, the first family of country music, and their extended family, the site of the Carter homeplace. The term "fold" in the Carter Family lexicon evokes both a place and a

\footnotetext{
${ }^{28}$ Ibid., 162.

${ }^{29}$ Williams, Homeplace, 20.

${ }^{30}$ Press release, undated, Pinelands Cultural Society Records, Box 1, "Notes to Press" folder.

31 “The Pinelands Cultural Society Newsletter," December 1975, Pinelands Cultural Society Records, Box 1, unfoldered material.

${ }^{32}$ Williams and Morrisey, "Constructions of Tradition," 162
} 
sense of family, community, and camaraderie. The stage at the Fold is meant to evoke a country cabin and features Carter Family photos and memorabilia. One can't escape the meaning that objects can hold.

The Pinelands Cultural Society constructed and assigned a sense of authenticity to Albert Music Hall by looking at least in part to the Grand Ole Opry for inspiration, and perhaps also to the Carter Family Fold, in a conscious nod to an iconic musical venue of the South. But as noted, they also brought in elements of the Alberts' cabin, as well as the Waretown auction building. ${ }^{33}$ These elements are seen most clearly in the interior of the Hall, particularly in the audience seating area and the stage.

While the stage set is meant to resemble the homemade front porch of the Albert brothers' cabin, the Pinelands Cultural Society made sure to utilize professional theater materials and standards to evoke their beloved Homeplace. For example, the stage flats are roughly four feet wide and are held in place by a wooden track. The cabin "walls" are flame-retardant muslin painted with super-saturated paints to avoid fading under stage lights. ${ }^{34}$ The stage has its own shed-style roof. The muslin that provides the backdrop for the stage is painted to look like exterior wooden shingles, with two red-curtained painted windows at the back of the stage and painted screen doors at either end. An American flag and a podium with microphone for the host are on the left of the stage. Cutouts of painted trees, evoking a forest look, stand at the edges of the stage.

As noted earlier, one wall of the hall is hung with instruments: guitars, banjos, fiddles, and an autoharp. The wall also features paintings of the Albert brothers and a handmade quilt. The opposite wall is adorned with antique farming implements and an array of items such as

\footnotetext{
${ }^{33}$ Everett, e-mail message to author, April 21, 2016.

${ }^{34}$ Ibid.
} 
washboards that signify "country" or "rural." This wall also features the work tools of the Pine Barrens native, in particular the tools of the baymen who made their living along the once-rich waterways of the area, as well as cranberry and blueberry harvesters. The décor of the hall emphasizes an older time in the Pine Barrens, lifestyles and surroundings that in many parts of the Pines have been disappearing or are gone completely. ${ }^{35}$ These markers of authenticity evoke the Homeplace and a time before modernity encroached on a secluded world. Despite the emphasis on the music and experience of the Sounds of the Jersey Pines, the significance of the homeplace as physical structure and its material accouterments cannot be underestimated.

While language and material culture have played important roles at Albert Music Hall, the music may be the best way the Alberts, the Pineconers, and others knew to keep the memory of their traditions and unspoiled environment alive. Indeed, Angus Gillespie and Tom Ayres have argued as much. ${ }^{36}$ In the 1970s Gillespie and Ayres spent significant time investigating Pine Barrens folklore, and while they suggest a distinctive Pine Barrens sound exists in the traditional Scotch and Irish fiddle music that the original settlers brought with them, they also found that the Pineconers and others played and performed a mixture of music that included “traditional, old-timey, string band, and contemporary pop-country selections." ${ }^{37}$ Pine Barrens residents heard fiddle tunes, ballads, and religious songs that were handed down and remained in the rural, isolated Pines a bit longer than they may have in other parts of the state. ${ }^{38}$ But we also know that the Albert brothers and other members of the Pineconers heard, even actively listened to, commercial country music that spoke to them as much as the old-time songs. Despite their relative isolation, from about the time of World War II, residents of the Pine Barrens and other

\footnotetext{
${ }^{35}$ Rory Crutchfield, "Discovering Authenticity? Harry Smith's Anthology of American Folk Music," Popular Music History, 4, no. 1 (2009): 9.

${ }^{36}$ Gillespie and Ayres, "Folklore in the Pine Barrens," 226.

${ }^{37}$ Ibid., 240.

${ }^{38}$ Ibid., 223.
} 
shore areas could listen to stations from Asbury Park and Atlantic City, not to mention West Virginia. $^{39}$

The Pinelands Cultural Society archives contain lists of songs performed at the earliest Waretown Auction shows. Many of the song titles reference the Pine Barrens, its towns, and its location in Ocean County. These song titles include "Ocean County Breakdown," "Double Trouble Queen," "Home in the Pines," "Ocean County Pineywoods," "The Homeplace," and "Come on Down to Waretown." ${ }^{, 40}$ Repeated themes of family and home resonate in the Sounds of the Jersey Pines repertoire in much the same way as Carter Family songs such as "My Clinch Mountain Home" and "Longing for Old Virginia" reference their Virginia mountain home. Two song titles in particular bring to mind Carter Family tune titles of memory and longing: "Albert Brothers Cabin in the Sky" and "I'll Still Write Your Name in the Sand."

In "Folk and Hillbilly Music in the Pines: Gladys Eayre and the Pineconers' Repertoire," Angus Gillespie explores how Gladys Eayre, Pinceoners vocalist and guitar player as well as their keeper of songs, came to learn songs that she introduced into the Pineconers' repertoire. Gillespie warns that one must not "assume their music comes straight out of tradition uncontaminated by the outside world, as some purists would have it." ${ }^{\text {41 }}$ Gillespie selected twelve songs from the Pineconers' repertoire and interviewed Eayre to find out how she first heard the songs. He discovered that Gladys first heard most of these songs on the radio and the others she learned from family. ${ }^{42}$

\footnotetext{
${ }^{39}$ James Osborne, "Echoes of Traditional Tunes Still Heard in New Jersey Pine Barrens," Philly.com, November 28, 2010, accessed December 4, 2015, http://articles.philly.com/2010-11-28/news/24953828_1_fiddle-music-musicaltradition-country-and-bluegrass.

${ }^{40}$ Notes, undated, Pinelands Cultural Society Records, Box 1, "Schedule of Music" folder.

${ }^{41}$ Gillespie, "Folk and Hillbilly Music in the Pines," 235.

${ }^{42}$ Ibid., 252.
} 
Richard Peterson discusses ways in which country music performers authenticate their claim to speak for their country identity. These can include nuances of voice and gesture and family heritage. ${ }^{43}$ The ability to demonstrate family heritage in country music, Peterson argues, may be the strongest asset of all. In the Pinelands Cultural Society records we see that the founders of the Pinelands Cultural Society including the Pineconers document their authenticity and reinforce their narrative in the Pines and as musicians. Gillespie and Ayres lay out a complicated web of generations of musical heritage and connections among Pine Barrens families and friends in "Folklore in the Pine Barrens."

The musicians and leaders of the Pinelands Cultural Society knew how key these family connections were to demonstrating authenticity and documenting a Pine Barrens that their audience members might not recognize. The Society's recording secretary in the Waretown Auction era, Arlene Ridgway, undertook local family histories with the presumed intent of documenting the strong ties the current musicians had to the Pine Barrens and to Pines musicians gone before. We catch glimpses of these family histories in the Pinelands Cultural Society records. For example, Arlene's husband, Merce Ridgway Jr., was a well-known bayman, musician, and songwriter in the Pines and his father was a member of the Pinehawkers, a band that achieved notoriety beyond the Pines in the 1940s. Ridgway is a last name long familiar in the Pine Barrens, with the earliest Ridgways in the area having arrived in the late 17 th century. ${ }^{4}$

While they were not natives and did not have Pine Barrens forebears, the Albert brothers became authentic through their long presence in, strong connection to, and lifestyle and activities in the Pines. The brothers played old time instruments and knew the same old tunes as their fellow Pinelands musicians. Notably, George and Joe first met one of the Pineconers and a very

\footnotetext{
${ }^{43}$ Peterson, Creating Country Music, 218.

${ }^{44}$ Cohen, Folk Legacies Revisited, 61.
} 
well-connected musician, Sam Hunt, as their Pines hunting guide many years before. ${ }^{45}$ The Pineconers in particular clung to the authenticity of all of their members when they developed the second iteration of the cabin at the Waretown Auction.

Janice Sherwood, a member of both the Pineconers and the Pinelands Cultural Society board, wrote about her childhood in the Pines and about her musical connections with her Pine Barrens relatives gone before, most notably her uncle Bill Britton, an accomplished fiddler and also a member of the Pinehawkers, in her unpublished memoir, Tunes and Tales. In it Sherwood relays stories behind the ways in which some songs she grew up with made their way to her childhood home in the Pine Barrens. She wrote that "Tunes came to Lacey (her town) in various ways. Always in someone's memory." 46 She goes on to relay the stories of transmission as she remembers them for a number of songs her grandfather and other relatives played at home. The only tune she discusses and points to a local source is "Glenn Cove Time," which she states her grandfather heard as a boy while out on Barnegat Bay one winter catching fish. He reportedly heard the song as it drifted across the water from another boat. Sherwood says that the title came from the location where her grandfather heard the song, the Glenn Cove section of Bayville, on Barnegat Bay. The word "time" was used because it was "a generic term for a rhythm pattern which was what Grandpa considered the melody."47

Sherwood states that other tunes her grandfather played were "Scots or Irish" and still others were about 'Indian maidens including 'Red Wing,' 'Rainbow,' 'Silver Bell,' and 'Lilly of the Prairie. $" 48$ Notably, Sherwood points out that one of the songs that made it into her uncle Bill

\footnotetext{
45 Ayres, "The Pinelands Cultural Society," 227.

46 Sherwood, "Tunes and Tales," 6.

${ }^{47}$ Ibid., 6.

${ }^{48}$ Ibid., 7.
} 
Britton's repertoire was a more contemporary song entitled "South." Britton heard the song on an Atlantic City jukebox during World War II. ${ }^{49}$

Sherwood included lyrics to twenty-three songs at the end of Tunes and Tales, some of which she may have heard or played during her youth at the end of her manuscript. These songs include "Soldier's Joy," "Devil's Dream," and "Jenny Lind Polka." One title notable, again, for its local connection is "The Hindenburg's Last Ride," which references the 1937 disaster at the nearby Naval Air Station Lakehurst. The song is credited to and copyrighted by Janice Sherwood. Perhaps this song originated in another rural region and was localized, with original lyrics replaced by a south Jersey locale and event. Angus Gillespie has noted a precedent for this in the Pines, for example folklorist Herbert Halpert collected the song "Mount Holly Jail," which makes appearances in Pineconers set lists, from the Pines region and learned it had been adapted from a song called, "Hard Times in Lancaster Jail." ${ }^{50}$ Gillespie pointed out that Ms. Sherwood has made similar changes to existing songs. ${ }^{51}$ The ability or decision to localize other regional tunes helps the musicians authenticate and validate the Pines as an iconic, meaningful, and romantic place, worthy of preservation and respect.

Gillespie's work with Gladys Eayre and Janice Sherwood, and the records of the Pinelands Cultural Society, demonstrate that the Pineconers and others were engaged in a true folk practice and that "not all songs are ancient, and that folk repertories are constantly changing." ${ }^{" 52}$ Additionally, like current Albert Music Hall performers, they changed their set lists to reflect audience tastes. The Pineconers developed lists that were appropriate for audiences that

\footnotetext{
${ }^{49}$ Ibid., 7.

${ }^{50}$ Gillespie, The Encyclopedia of New Jersey, 279.

${ }^{51}$ Gillespie, conversation with author, July 2015.

${ }^{52}$ Myers and Wilton, "folk music," The Oxford Companion to Music. Oxford Music Online.
} 
contained middle-aged or, at the time, their peer audiences, high school and college students and young children (when visiting schools). ${ }^{53}$

When it comes to the music of Albert Music Hall, authenticity is not fixed. It changes with time and tastes, as does its assigned value. ${ }^{54}$ If the powerful notion of authenticity is a changeable, often knowing construction whose validity rests in its reception, then as much as it is rooted in a Pine Barrens past, what is most real and true about Albert Music Hall is its ability not only to persist but to adapt and flourish through the music that emanates from the stage and Pickin' Shed every weekend. The Sounds of the Jersey Pines is the Pineconers and all the local bands playing music from and about the Pine Barrens, but it is also the popular and commercial music of the 20th century. In writing about the music of the rural South, country music historian Bill C. Malone defined "white rural music...as music and dance that white rural people accepted as their own. Rural southerners made their own music or inherited it from their forebears, but they also absorbed songs...from whatever source was available within the total southern context in which they lived." 55 If we analogize to the music of the New Jersey Pine Barrens, we can see that, all along, the musicians of the Homeplace and the Sounds of the Jersey Pines absorbed the musical influences around them, from Scots-Irish tunes to what was heard over commercial radio that could be picked up in the Pines. Today's retirement home crowds at Albert Music Hall retain their love of and interest in the music of their youth, whether they themselves grew up in the Pine Barrens or in surrounding Ocean County, or whether, like the Albert brothers, they come from a more populated, industrial, and commercially influenced part of the state or broader region.

\footnotetext{
${ }^{53}$ Gillespie, "Folk and Hillbilly Music in the Pines," 252-254.

${ }^{54}$ Crutchfield, "Discovering authenticity?" 10-11.

55 Bill C. Malone, Singing Cowboys and Musical Mountaineers: Southern Culture and the Roots of Country Music (Athens: The University of Georgia Press, 2003), 9.
} 
The Pinelands Cultural Society today states that its primary purpose is preserving the spirit of the Albert cabin gatherings. They view their mission as "maintain[ing] the feel, fun and camaraderie of the "original' gatherings to the greatest extent practical." 56 They emphasize an authenticity of feeling, and it is the playing of music, from old-time to popular country, that has always created that feeling. The variety of the music of Albert Music Hall, past and present, combined with its house rules and material trappings, serves to create and encourage a certain atmosphere and connection to a vibrant Pines past. The response of the audience to the music they recognize and enjoy is a key factor in the authenticity work of the musicians. Audiences from the Homeplace to the current Albert Music Hall have stretched the boundaries of traditional, vernacular music ${ }^{57}$ and what is considered an authentic Pine Barrens musical experience, thereby helping this incongruous New Jersey musical site to thrive.

Christine A. Lutz is New Jersey Regional Studies Librarian and Head of Public Services in Special Collections and University Archives, Rutgers University. She has contributed to The Encyclopedia of New Jersey and the Princeton University Library Chronicle. She holds an undergraduate degree in English from the University of Georgia, an MLS from Rutgers University, and an MA in American Studies from the University of Maryland.

\footnotetext{
56 “Frequently Asked Questions," Albert Music Hall, accessed November 1, 2015, http://www.alberthall.org/UnderstandingPCSandAMH.htm.

${ }^{57}$ Paul Tyler, "Hillbilly Music Re-imagined: Folk and Country Music in the Midwest," (Journal of American Folklore 127 [504]): 62.
} 